Research Article

\title{
Growth performance of the green tiger shrimp penaeus semisulcatus raised in biofloc systems
}

\begin{abstract}
Biofloc technology (BFT) is a technique of enhancing water quality in aquaculture to produce a microbial biomass or a "biofloc" that could be consumed by the cultured animals as a food source. For this purpose, an intensive feed trial for the green tiger shrimp Penaeus semisulcatus was conducted throughout an indoor system to determine the benefits of biofloc technology in water quality control and growth performance of the shrimp. The impact of substrate on the shrimps' performance in this system was also evaluated. In addition, the nutritive quality of the shrimps' flesh was assessed. Water quality was enhanced in the biofloc systems in terms of dissolved oxygen, $\mathrm{pH}$, unionized ammonia and nitrate. Growth rates and weight gains of shrimps in the biofloc tanks increased significantly while the feed conversion ratios decreased with increasing the C: $\mathrm{N}(16: 1)$ ratio. The effect of substrate on the survival rate of shrimps is also discussed.
\end{abstract}

Keywords: Biofloc, Penaeus semisulcatus, Microbial biomass, Substrate, Growth performance
Volume 2 Issue 5 - 2015

\section{Aya S Hussain,' Deyaaedin A Mohammad,' Elham M Ali,' Wafaa S Sallam² \\ IDepartment of Environmental Science, Suez University, Egypt 2Department of Marine Science, Suez Canal University, Egypt}

Correspondence: Aya S Hussain, Department of Environmental Science, Faculty of Science, Suez University, Suez, Egypt,Tel 01002642135,Email ayasaied04@yahoo.com

Received: July 01, 2014 | Published: September 04, 2015
Abbreviations: BFT, Biofloc Technology; IBW, Initial Body Weight; FBW, Final Body Weight; WG, Weight Gain; ADG, Average Daily Gain; SGR, Specific Growth Ratio; FCR, Feed Conversion Ratio; SAFICO, Shrimp and Fish International Company; PER, Protein Efficiency Ratio; SR, Survival Rate; THB, Total Heterotrophic Bacteria; HSD, Honestly Significant Differences; THB, Total Heterotrophic Bacterial Population

\section{Introduction}

Traditional penaeid shrimp culture has a long proven history using pond culture in tropical climates. The global shrimp market has expanded from less than $\$ 1$ billion in 2000 to $\$ 5.8$ billion (US) in $2005 .{ }^{1}$ To meet the growing demand on shrimp, the industry is shifting from extensive rearing systems to more intensive rearing systems. ${ }^{2}$ Increasing stocking density of fish or shrimp in ponds usually increases the deterioration of pond sediment, ${ }^{3}$ increases the susceptibility of shrimps to disease, ${ }^{4}$ decreases growth of shrimp, ${ }^{3}$ increases pressure on natural food resources, ${ }^{5}$ reduces food conversion efficiency, ${ }^{6}$ and rises the total food costs. ${ }^{7}$ In aquaculture, the cost of the supplementary diets is predominantly due to the cost of protein component in general and fish meal in particular. ${ }^{8}$ Fishmeal is considered an essential ingredient in marine shrimp diets because of its balanced amount of essential amino acids, fatty acids, vitamins, minerals and palatability. ${ }^{9}$ Tacon $\&$ Metian $^{10}$ reported that the aquaculture industry consumed $68.2 \%$ of global fishmeal production in 2006; however, fishmeal production has remained relatively constant since 1985 at about 7 million tons per year. ${ }^{11}$ The steady growth of aquaculture and consequent increase in demand for fishmeal has caused a significant increase in fishmeal prices in the last decade. ${ }^{12}$ It has led to an increase in feed prices reducing the use of this ingredient in diets for animals. ${ }^{13}$ Despite the stabilization in the production of fishmeal, aquaculture production continues to grow year after year. In part, technological advances have allowed significant improvements in the feed efficiency of fish and shrimp. ${ }^{10}$ Nevertheless, dependence on fishmeal remains high, affecting the profitability of aquaculture. ${ }^{14}$ Thus, the increasing demand for fishmeal, combined with over-exploitation of fish stocks, has spurred a search for cheaper and sustainable protein ingredients to reduce or eliminate the use of fishmeal in aquaculture diets. ${ }^{15}$
With the rapid expansion and intensification, however, there is also a growing concern about the ecological sustainability of shrimp farming. ${ }^{16}$ The cultured shrimp retain only $20-30 \%$ of feed nutrient; therefore, $70-80 \%$ of high dietary protein is excreted and accumulated in water, which finally leads to water deterioration. ${ }^{17}$ Moreover, worsening of water quality has resulted in disease outbreaks and heavy financial losses. ${ }^{18}$ Such environmental issues have created a large demand for productive, efficient and sustainable shrimp farming systems that have low impact on the environment and are more likely to be free of disease. ${ }^{19}$ One of the potential management measures to improve production and nutrients retention in shrimp farming systems is the application of biofloc technology by means of manipulating the carbon/ nitrogen ratio $\left(\mathrm{C} / \mathrm{N}\right.$ ratio) ${ }^{20}$ If carbon and nitrogen are well balanced according to either the use of lower protein diet and/ or supplying additional carbon sources, e.g. glucose, sucrose, and starch to the pond, the inorganic nitrogen components (ammonia, nitrite, and nitrate) in pond will be converted into bacterial biomass. ${ }^{20}$ As such, nutrients from excretion and remnant feed are recycled into bacterial biomass and formed biofloc which can be taken up as an additional feed for aquatic animals. ${ }^{21}$

Biofloc technology has been applied and developed in high intensive farming systems of several shrimp species, such as Penaeus monodon, Litopenaeus vannamei, and Macrobrachium rosenbergii. ${ }^{22-24}$ However, due to the specific hiding behavior of P. semisulcatus by day light, little is known about the practicability of biofloc technology for its intensive farming. Nevertheless, Megahed ${ }^{25}$ was able to develop an intensive farming system for P. semisulcatus at the Shrimp and Fish International Company (SAFICO), South Sinai, Egypt. In his study, he showed that BFT could provide a solution to reduce feed cost and enhance water quality. The use of artificial substrates is a management strategy employed in the growth of aquatic organisms to improve efficiency in culture tanks. Polyethylene and polypropylene screens, bamboo, plastic bottles and commercial products (Aquamats TM) have been used as substrates in growth tanks. ${ }^{26}$ In experiments with post-larvae and juvenile marine shrimp, the use of substrates is frequently associated with improved performance by the shrimp. ${ }^{27}$ In intensive cultures, substrates have been used in an effort to mitigate the negative effects of increasing the stocking density. ${ }^{28}$ Abdussamad 
\& Thampy ${ }^{29}$ suggested that substrates provide an additional surface for the shrimps, which reduces their competition for space and negative behavioral interactions such as cannibalism. In this study, we conducted an intensive farming trial for P.semisulcatus using indoor biofloc systems to determine the benefits of biofloc technology in water quality control and growth performance of the shrimp. The impact of substrate on the shrimps' growth performance in this system was also evaluated. In addition, the nutritive quality of the shrimps' flesh was assessed.

\section{Materials and methods}

The objective of this experiment was to study the effect of BFT application on the water quality and growth performance of the green tiger shrimp P. semisulcatus reared in the laboratory.

\section{Preparation of experimental tanks}

Eight square fiber glass tanks with dimensions of $60 \times 60 \times 35 \mathrm{~cm}$ (length $\times$ width $\times$ height) were used in this experiment. The tanks were cleaned with formalin, washed with water then left to dry. Each tank was filled with 80 liters of sea water with a salinity of $30 \mathrm{gL}-1$ and aerated using a silicone tube connected to an air blower. Salinity was measured using a Refractometer. Water temperature was maintained at $30^{\circ} \mathrm{C} \pm 1$ by means of eight water heaters. The tanks were covered completely with plastic films $(0.4 \mathrm{~mm})$ to reduce evaporation. The tank volume was maintained constant by adding one liter of tap water weekly to replace the loss due to evaporation.

\section{Experimental diet}

The prepared diet was used to feed shrimps in the control tanks as well as those in the biofloc treatment tanks.

Composition: The diet was formulated to be equivalent to the levels of crude protein, crude fat, total ash and crude fiber required for the culture of this shrimp. Composition and cost of the dietary ingredients is shown in Table 1 (all ingredients were locally purchased). The proximate analysis of the diet (Table 2) was carried out at the Department of Nutrition and Clinical Nutrition, Faculty of Veterinary Medicine, Suez Canal University, Egypt.

Table I Composition and cost of the dietary ingredients used in the feeding trial

\begin{tabular}{lll}
\hline Ingredients & $\begin{array}{l}\text { Experimental diet (G/ } \\
\text { I 00g Dry matter) }\end{array}$ & \begin{tabular}{l} 
Cost (US $\mathbf{2 0 ~ / ~} \mathbf{~ K g}$ \\
\hline Fish meal (Local)
\end{tabular} \\
\hline Shrimp meal & 20 & 0.7 \\
Soybean meal & 20 & 0.7 \\
Wheat flour & 20 & 0.7 \\
Corn meal & 19 & 0.3 \\
Gelatin (Binder) & 0.5 & 0.3 \\
Vitamin premix & 0.025 & 1.1 \\
Mineral premix & 0.025 & 1.4 \\
Manufacture cost & & 1.4 \\
\hline
\end{tabular}

Preparation: Exact amounts of dried and finely ground ingredients were mixed thoroughly. Sufficient amount of hot water was added to dissolve the gelatin powder, and then the solution was added to the ingredients and mixed until stiff dough was produced. The dough was pressed into pellets $(2 \mathrm{~mm})$ using a commercial food mincer/ grinder then dried for $24 \mathrm{hrs}$ in a laboratory oven at $60^{\circ} \mathrm{C}$. They were then packed in a plastic container at room temperature for subsequent use.
Table 2 Proximate composition of the experimental diet

\begin{tabular}{ll}
\hline Proximate analysis & $\%$ \\
\hline Dry matter (DM) & 92.8 \\
Moisture & 7.2 \\
Crude protein & 23.4 \\
Crude fat & 3.2 \\
Crude Fiber (CF) & 6.6 \\
Ash & 15.4 \\
Nitrogen Free Extract (NFE) & 44.3 \\
Gross energy* & 3707.7 \\
\hline
\end{tabular}

*Gross energy was calculated on the basis of $5.64,4.1$ I and $9.44 \mathrm{Kcal}$ GE/g protein, NFE and fat, respectively.

\section{Transportation of shrimps}

Wild specimens were obtained from Shatta, Damietta, Egypt and transferred in a closed plastic tank supplied with aeration using a portable battery air pump.

\section{Acclimatization}

Upon reaching the laboratory, shrimps were transferred to the prepared tanks using small containers. The containers were allowed to float on the water surface of the tank for 30 minutes. They were lowered gradually into the tanks and the tank water was sprinkled slowly into the containers for 10 minutes to equalize with tank water quality. The shrimps were considered acclimatized when they started to get out of the container and swim into the tanks. Shrimps were left without feeding during the first day then adapted gradually to the prepared diet and aquarium conditions for one week.

\section{Experimental design}

The experiment was performed in the Mariculture laboratory, at the Department of Marine Science, Suez Canal University, Ismailia, Egypt, for eight weeks (from April 16th -June 16th 2014). The previously prepared fiber glass tanks were used. Thirty PVC pipes of 1 inch diameter and $20 \mathrm{~cm}$ length were placed at the bottom of each tank to act as artificial burrows (substrate) for shrimps. Three replicates for two biofloc treatments (with and without substrate) were made. A control tank for each treatment was used and those were equipped with an automatic mechanical filtration filter (Model Jinzlian, China). Thirty juvenile shrimps (with a mean weight ( \pm standard deviation) of $0.5 \mathrm{~g} \pm 0.1$ ) were stocked per tank, resulting in a density of 100 shrimps/ $\mathrm{m} 2$. The daily feeding rate was $10 \%$ of their body weight at the beginning of experiment, and reduced gradually to $5 \%$ body weight at the end of the culture period. The amount of feed given to the shrimps increased gradually every two weeks of the experimental period $(1.5 \mathrm{~g}, 3.15 \mathrm{~g}, 4 \mathrm{~g}$ and $5.5 \mathrm{~g}$, respectively). In order to stimulate bacterial growth, an amount of rice meal was added daily after the addition of the feed in the biofloc tanks to maintain a $\mathrm{C}: \mathrm{N}$ ratio of (16:1) and increased gradually every two weeks of the experimental period $(0.7 \mathrm{~g}, 1.5 \mathrm{~g}, 2 \mathrm{~g}$ and $2.7 \mathrm{~g})$.

\section{Water quality parameters}

Water quality in each tank was monitored twice a week between 10:00 am and 12:00 pm for dissolved oxygen (DO), $\mathrm{pH}$, temperature, nitrate (NO3) and unionized ammonia (NH3). $\mathrm{pH}$ and temperature were measured by means of a Multimeter (Crizon, mm 40). Dissolved oxygen was measured by a digital oxygen meter. Nitrate and unionized ammonia were measured using colorimetric estimations of a commercial kit (API ${ }^{\circledR}$ master test kit). Total heterotrophic bacteria 
(THB) count in the water was estimated following the standard procedure $^{30}$ and expressed as colony-forming units per $\mathrm{ml}$ (CFU ml$1)$.

\section{Growth performance analysis}

Upon termination of the 8-week growth trial, final weights of the remaining shrimp were obtained as shrimp weight per tank (FBW). Weight gain $(\mathrm{WG}=$ final weight $[\mathrm{FBW}]$ - initial weight $[\mathrm{IBW}])$; average daily gain $(\mathrm{g} /$ shrimp/day $):(\mathrm{ADG}=[\mathrm{FBW}-\mathrm{IBW}] /$ days $)$; specific growth rate $(100 \times[\ln \mathrm{FBW}-\ln \mathrm{IBW}] /$ days $)$; feed conversion ratio $(\mathrm{FCR}=$ Dry feed consumed $/ \mathrm{WG})$; protein efficiency ratio $(\mathrm{PER}$ $=$ total $\mathrm{WG} /$ total protein consumed $)$ and survival $(\mathrm{SR}=100 \times$ final shrimp number /initial shrimp number) for each dietary treatment were determined according to Ricker; ${ }^{31}$ Felix \& Sudharsan. ${ }^{32}$ and Venkat et al. ${ }^{33}$

\section{Nutritive quality of the shrimps' flesh}

The shrimps were washed with deionized water to remove any adhering contamination, and then drained over filter paper. For each group of individuals the exoskeletons were peeled off and the flesh was oven dried at $70^{\circ} \mathrm{C}$ then ground into fine powder. Protein, carbohydrate and lipid contents were estimated by adopting the standard methods of Lowry et al. ${ }^{34}$ Dubois et al. ${ }^{35}$ and Folch et al., ${ }^{36}$ respectively. Shrimp flesh was analyzed for moisture and ash content. ${ }^{37}$ The carbohydrate content was estimated according to Merrill \& Watt: ${ }^{38}$ carbohydrate $=100-($ ash + crude protein + moisture + total fat $)$. Samples were analyzed at the Department of Nutrition and Clinical Nutrition, Faculty of Veterinary Medicine, Suez Canal University, Egypt. The obtained data was pooled for all replicate samples and the average was calculated.

\section{Statistical analysis}

Statistical analysis was performed using SYSTAT (V.10.2.05, 2002). Differences in water quality were considered significant at $P<0.05$. Analysis of Variance (ANOVA) was used to determine the effect of different culture systems on shrimp performance. When appropriate, a Turkey's HSD (Honestly Significant Differences) posthoc test was employed to check for differences between means. The $5 \%$ significance level was applied for all tests.

\section{Results}

\section{Water quality parameters}

Dissolved oxygen (DO): DO concentrations in the control tanks were higher than the biofloc treatment tanks throughout the culture period (Figure 1). The values decreased gradually from $6.07 \mathrm{mg} / \mathrm{L}$ until 5.2 and $4.07 \mathrm{mg} / \mathrm{L}$ in the control and biofloc tanks, respectively. Variations in DO concentrations between the two treatments were significantly different $(P<0.001)$. However, no significant difference was recorded in the treatments with the presence or absence of substrate $(P<0.070)$.

Hydrogen ion concentration ( $\mathbf{p H})$ : The $\mathrm{pH}$ values in the control tanks were higher compared to the biofloc treatment tanks (Figure 2). The values in the biofloc tanks showed minor differences during the culture period ranging between 7.6-7.8. On the other hand, values in the control tanks increased relatively from 7.6 to 8.2. They remained more or less constant in both treatments (ranging between 8.13$8.17 ; 7.67-7.63$, respectively) from the 7 th week until the end of the experiment. Differences in $\mathrm{pH}$ values between the two treatments were significantly different $(P<0.001)$ but not significantly different with the presence or absence of the substrate in both treatments $(P<0.367)$.

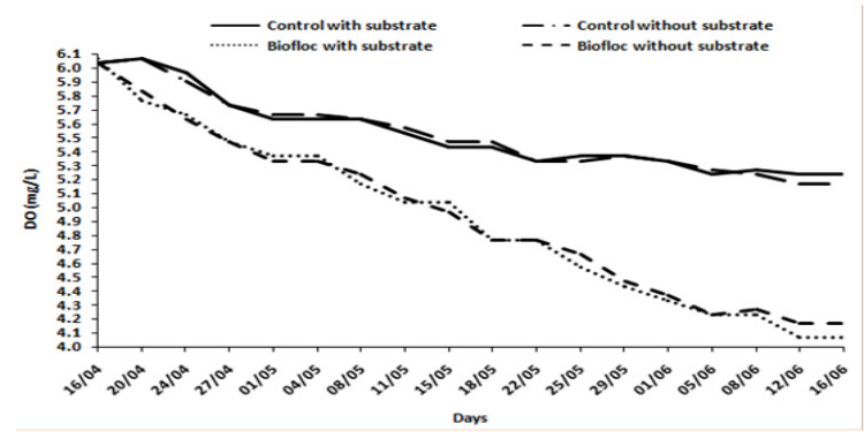

Figure I Variations in DO concentrations in the different treatments throughout the experimental period.

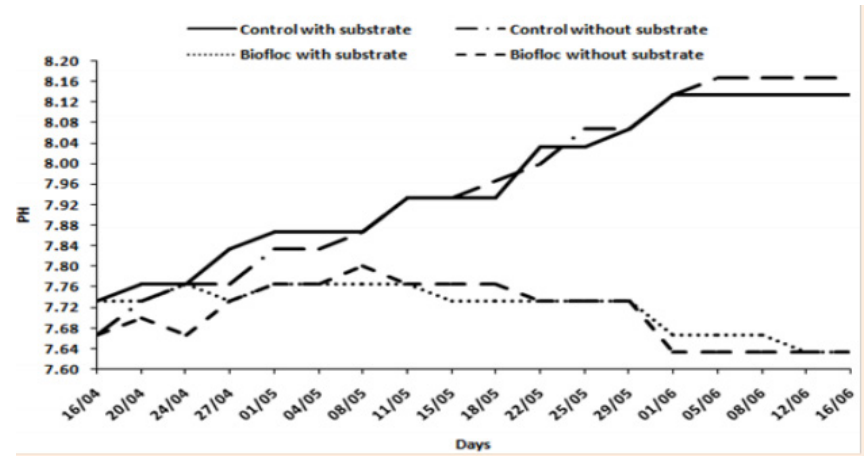

Figure $\mathbf{2}$ Variations in $\mathrm{pH}$ values in the different treatments throughout the experimental period.

Unionized ammonia (mg/L): Unionized ammonia concentrationsin the control tanks were higher than the biofloc treatment tanks, increasing gradually from 0.07 to $1.1 \mathrm{mg} / \mathrm{L}$ (Figure 3). In contrast, ammonia in the biofloc tanks remained relatively constant (ranging between $0.07-0.09 \mathrm{mg} / \mathrm{L}$ ). Concentrations in both treatments were significantly different $(P<0.001)$, but no significant difference was recorded in the treatments with the presence or absence of the substrate $(P<0.945)$.

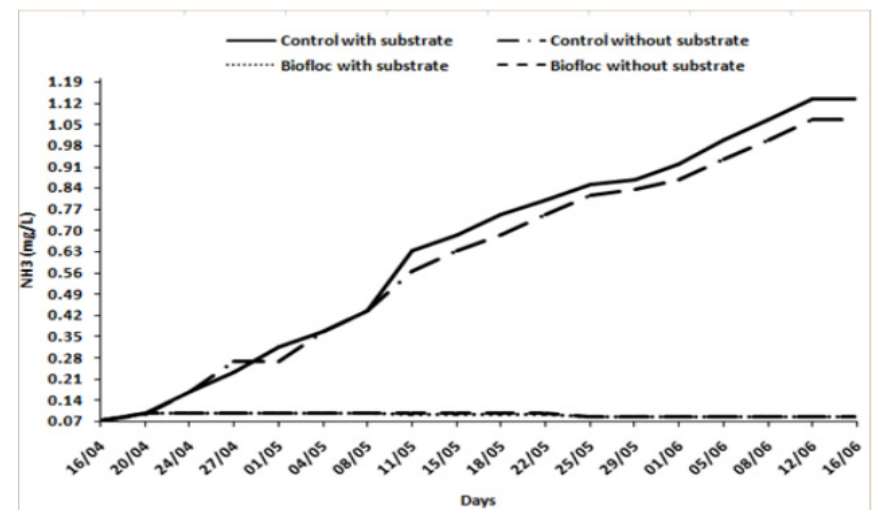

Figure 3 Variations in concentrations of unionized ammonia in the different treatments throughout the experimental period.

Nitrate $(\mathbf{m g} / \mathbf{L})$ : Nitrate concentrationsin the control tanks increased from less than $5,10,20,40$ reaching $60 \mathrm{mg} / \mathrm{L}$, respectively. In contrast, the levels of nitrate in the biofloc treatment tanks showed approximately the same values (less than $5 \mathrm{mg} / \mathrm{L}$ ) throughout the culture period.

Total heterotrophic bacterial population (THB): The total numbers of heterotrophic bacterial cells in the biofloc treatment tanks increased 
greatly from 25 to $125 \mathrm{CFU} / \mathrm{ml}$ (Figure 4). In contrast, their numbers in the control tanks remained more or less constant (ranging between 21 and $23 \mathrm{CFU} / \mathrm{ml}$ ). The total numbers of heterotrophic bacteria in both treatments were significantly different $(P<0.001)$ but no significant difference was recorded in the treatments with the presence or absence of the substrate $(P<0.640)$.

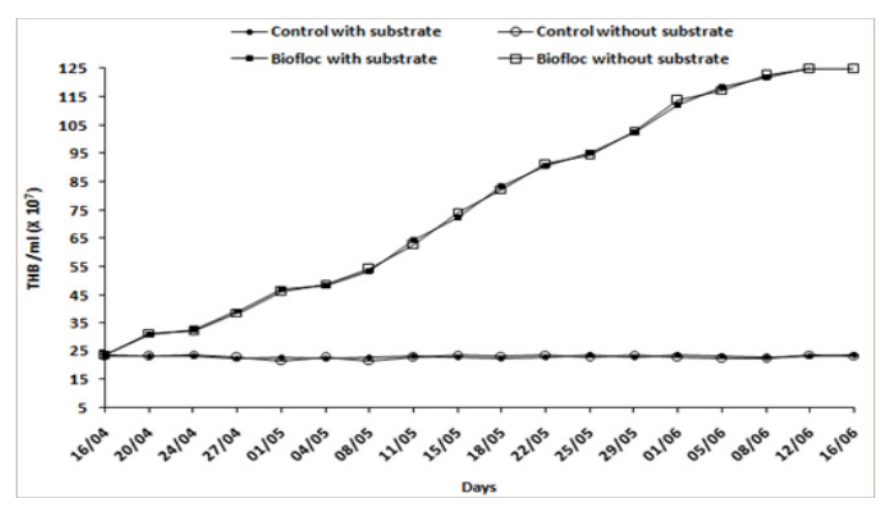

Figure 4 Variations in the total numbers of heterotrophic bacterial cells in the different treatments throughout the experimental period.

\section{Growth performance analysis}

Final body weight (FBW), weight gain (WG), average daily gain (ADG) and specific growth ratio (SGR) values showed minor differences between the two treatments (Table 3). However, the feed conversion ratio (FCR), protein efficiency ratio (PER) and survival ratios (SR) in both treatments (in the presence of substrate) showed better values than those without substrate. Differences in the final weights of $P$. semisulcatus in both treatments were significantly different $(P<0.001)$.

Values in the same row with
letters are significantly different $(P<0.05)$. SD: Standard Deviation; FBW: Final Body Weight; WG: Weight Gain; ADG: Average Daily Gain; SGR: Specific Growth Ratio; FCR: Feed Conversion Ratio; PER: Protein Efficiency Ratio; SR: Survival Rate

\section{Nutritive quality of the shrimps' flesh}

Moisture was the highest component in the shrimps' flesh in both treatments (Table 4). The flesh of shrimps raised in the biofloc tanks exhibited relatively higher values of crude protein percentages (20.19 $\%)$ than those raised in the control tanks (18.99\%). Carbohydrates, fat and ash were the lowest components obtained with minor differences between both treatments.

\section{Discussion}

The consumption of biofloc by shrimp has demonstrated several benefits such as the improvement of the growth rate, ${ }^{39}$ decrease of food conversion ratio (FCR) and associated costs in feed. ${ }^{40}$ Growth enhancement has been attributed to the bacterial nutritional components of the biofloc; up to $30 \%$ of the conventional feeding ration can be lowered due to biofloc consumption in shrimp..$^{40}$ The present study aimed to determine the benefits of biofloc technology in water quality control and growth performance of the green tiger shrimp. The impact of substrate on the shrimps' performance in the biofloc system was also evaluated in the presence of high stocking density. In addition, the nutritive quality of the shrimps' flesh was assessed.

Table 3 Mean values of the final weights and growth performance parameters of Penaeus semisulcatus in the four treatments at the end of the eight weeks experimental period

\begin{tabular}{lllll}
\hline Treatment & $\begin{array}{l}\text { Control } \\
\text { With substrate }\end{array}$ & Without substrate & $\begin{array}{l}\text { Biofloc } \\
\text { With substrate }\end{array}$ & Without substrate \\
\hline FBW \pm SD & $4.73 \pm 0.3 \mathrm{a}$ & $5.36 \pm 0.4 \mathrm{~b}$ & $5.52 \pm 0.4 \mathrm{c}$ & $5.7 \mathrm{I} \pm 0.5 \mathrm{~d}$ \\
WG $(\mathrm{g})$ & 4.23 & 4.86 & 5.02 & $5.2 \mathrm{I}$ \\
$\mathrm{ADG}(\mathrm{g})$ & $0.07 \mathrm{I}$ & $0.08 \mathrm{I}$ & 0.084 & 0.087 \\
SGR $(\% /$ day) & 3.75 & 3.95 & 4 & 4.06 \\
FCR & 3.31 & 2.88 & 2.79 & 2.69 \\
PER & $2.4 \mathrm{I}$ & 1.19 & 3.23 & 1.44 \\
SR $(\%)$ & 76.67 & 33.33 & 87.78 & 37.78 \\
\hline
\end{tabular}

Table 4 Nutritive quality of the flesh of $P$. semisulcatus in the two treatments (expressed as \% fresh weight basis)

\begin{tabular}{lll}
\hline Parameter & $\begin{array}{l}\text { Treatments } \\
\text { control }\end{array}$ & Biofloc \\
\hline Moisture & 75.07 & 73.64 \\
Crude protein & 18.99 & 20.19 \\
Crude carbohydrate & 2.13 & 2.22 \\
Crude fat & 1.48 & 1.54 \\
Ash & 2.33 & 2.41 \\
\hline
\end{tabular}

\section{Water quality parameters}

Formulated diets and water quality values were considered optimal for shrimp culture. ${ }^{41,42}$ This allowed direct comparisons between the water quality parameters in the control and biofloc treatments to be made.

Dissolved oxygen (DO): The recorded values of DO were within the good range for all the aquatic organisms. ${ }^{43}$ DO concentrations decreased in both treatments over time. This could be attributed to the high stocking density (30 pcs per tank, resulting in a density of 100 shrimps/ m2) which agrees with the study of Allan \& Maguire $^{5}$ who reported a decline in the growth of $P$. monodon juveniles as densities increased in model farming ponds. The concentrations of dissolved oxygen in the biofloc tanks tended to decrease more rapidly than the control tanks. This could be due to the increased $\mathrm{C}$ : $\mathrm{N}$ ratio which stimulates the growth of the heterotrophic bacteria which in turn require oxygen for their growth. This finding is in accordance with that of Landman et al. ${ }^{44}$ who determined the hypoxia sensitivity of ten 
fish and invertebrate species in plastic aquaria in New Zealand and found that there was a decrease in dissolved oxygen concentrations with the increase of $\mathrm{C}$ : $\mathrm{N}$ ratio. Sun et al. ${ }^{45}$ studied the supplementation and consumption of dissolved oxygen and their seasonal variations in a shrimp pond. They proved that the concentrations of dissolved oxygen had a significant negative correlation with the numbers of heterotrophic bacteria. Bacteria have been reported to contribute as much as $77 \%$ of the total oxygen consumption in fish ponds. ${ }^{46}$

Hydrogen ion concentration (pH): Values of $\mathrm{pH}$ in the present study were within the preferable range for penaeid shrimps. ${ }^{41}$ The values in the control tanks increased relatively from 7.6 to 8.2. Ebeling et al. ${ }^{47}$ reported that the photosynthesis and nitrification processes that are likely to occur in control system might have resulted in $\mathrm{pH}$ increase. These processes could alter $\mathrm{CO} 2$ concentration and the buffering capacity of the water.

On the other hand, levels of the $\mathrm{C}$ : $\mathrm{N}$ ratios in the biofloc tanks have significantly influenced the values of $\mathrm{pH}$ during the culture period by keeping them more or less constant. This could be related to the presence of heterotrophic bacteria which consume organic matter and cause the increase in the level of water inorganic carbon (CO2) and decrease the values of $\mathrm{pH} . \mathrm{pH}$ usually declines as the redox potential declines as a result of microbial activity ${ }^{48}$ Ebeling et al.$^{47}$ stated that nitrogen uptake by heterotrophic process that likely to dominate BFT system consumes alkalinity half than nitrification ( $3.57 \mathrm{~g}$ alkalinity $/ \mathrm{g}$ $\mathrm{NH} 4+-\mathrm{N}$ ). They also concluded that as alkalinity concentration relates to the buffering capacity of water, the effect of the high concentration of $\mathrm{CO} 2$ resulted from fish and microbial respiration on water $\mathrm{pH}$ could sufficiently buffered in BFT systems.

Unionized ammonia and nitrate $(\mathrm{mg} / \mathrm{L})$ : Nitrogenous constituents were at safe levels for ammonia ${ }^{49}$ and nitrate. ${ }^{50}$ Ammonia and nitrate concentrationsin the control tanks increased gradually from 0.07 to $1.1 \mathrm{mg} / \mathrm{L}$ and 5 to $60 \mathrm{mg} / \mathrm{L}$, respectively throughout the culture period which can be referred to the increase in the stocking density of shrimps. Similar results have been reported in studies performed in different parts of the world. ${ }^{51,52}$

Concentrations of ammonia and nitrate in the biofloc tanks decreased as the levels of $\mathrm{C}: \mathrm{N}$ ratio $(16: 1)$ increased. This result implies that rice meal addition (as a carbon source) had an obvious effect on the inorganic nitrogen reduction through stimulation of the bacterial growth. Furthermore, concentrations of ammonia and nitrate were negatively associated with the numbers of bacteria (Figures 3 , 4). These findings are in agreement to those reported by Tezuka ${ }^{53}$ and Hoch et al. ${ }^{54}$ who stated that addition of carbon diminished inorganic nitrogen due to increasing uptake of $\mathrm{NH} 4+$ by bacteria. Zero water exchange ponds using carbon source enabled the control of the inorganic nitrogen accumulation through a balanced ratio of carbon to nitrogen in the feed..$^{20,55,56} \mathrm{In}$ addition, Stuart et al. ${ }^{57}$ raised the tiger shrimp Penaeus monodon in zero water exchange model using a daily carbon source (tapioca powder) and concluded that the addition of carbon promoted the microbial community and improved the water quality.

Total heterotrophic bacterial population (THB): There was a significant increase in the total number of heterotrophic bacteria with increased levels of $\mathrm{C}$ : $\mathrm{N}$ ratio in the biofloc tanks (Figure 4). This indicates that bacteria required carbon from the carbon source (rice meal) in order to multiply their cells. Middelboe et al. ${ }^{58}$ studied bacterial utilization of dissolved free amino acids, dissolved combined amino acids and ammonium in the Delaware Bay estuary in the US and stated that the addition of glucose increased the number of heterotrophic bacteria in water. Similarly, some previous investigators ${ }^{22,55,56}$ found that the numbers of heterotrophic bacteria increased in response to increasing levels of $\mathrm{C}: \mathrm{N}$ ratio in penaeid shrimp culture.

\section{Growth performance analysis}

Impact of the different treatments on growth parameters: The mean final weight, weight gain (WG), average daily gain (ADG) and the specific growth rate (SGR) in the control tank (without substrate) showed relatively higher values than that with substrate. On the other hand, the same parameters were slightly higher in biofloc tanks that had no substrate than those with substrate. This could be attributed to the high mortality of shrimps in absence of the substrate which resulted in decreasing the stocking density. Wyban et al. ${ }^{59}$ studied the impact of stocking density on Penaeus vannamei growth rates in manure-fertilized ponds and reported that growth declined while both yield and density increased. The low shrimp performance in intensive cultures has been attributed to the negative social interactions between individuals which may result in an inhibitory effect such as aggressiveness ${ }^{60}$ or stimulate cannibalism. ${ }^{29}$ Otoshi et al. ${ }^{61}$ and Zhang $^{26}$ suggested that substrates diminish the negative effects of intensification as they provide more space for the shrimp and reduce the stress that can lower their performance.

Growth rates and weight gains of shrimps in the biofloc tanks increased significantly while the feed conversion ratios decreased with increased C: $\mathrm{N}(16: 1)$ ratio compared to those obtained from the control tanks. These results are in accordance with Avnimelech ${ }^{20}$ who reported that the growth rates of fishes in tilapia commercialscale ponds in Israel treated with carbon: nitrogen ratio of 16.6:1 was significantly higher than those grown in ponds with carbon: nitrogen ratio of 11.1: 1, while mortality of fishes, feed conversion rate and feed cost coefficient in treatment with carbon: nitrogen of 16.6:1 were significantly lower than in treatment with carbon: nitrogen of 11.1: 1 .

Protein efficiency ratios of the shrimps in the biofloc tanks were higher than the control tanks. Hari et al. ${ }^{62}$ conducted one indoor and one on-farm trial in India to evaluate the effect of control of carbon/ nitrogen ratio $(\mathrm{C} / \mathrm{N}$ ratio) by addition of carbohydrate to the water column in extensive types of Penaeus monodon culture systems and reported that protein conversion efficiency of the shrimps in carbohydrate added ponds were higher, revealing that the input feed protein along with the microbial protein was effectively converted by shrimps into biomass.

\section{Impact of the different treatments on survival rates}

In our study, although the water quality parameters were appropriate for shrimps' growth, the survival rate of the shrimps in the control and biofloc tanks that lacked the substrate was lower to a great extent than those with substrate. Suresh $\& \operatorname{Lin}^{63}$ studied the effect of stocking density on the water quality and production indices of red tilapia in a recirculated water system and reported a negative correlation between stocking density of fish with growth as well as other production parameters. In intensive culture systems, however, the use of shrimp that are genetically selected for fast growth in high densities and the use of formulated feed for such conditions are considered key factors for successful cultivation. ${ }^{61}$

Here, the use of the green tiger shrimp that was not specifically selected for intensive systems may have contributed considerably to the lower survival rate recorded in the tanks that had high stocking density and lacked the substrate. Araneda et al. ${ }^{64}$ and Otoshi et al. ${ }^{61}$ suggested that crowding at high densities causes stress on the shrimp, and can compromise performance. Stressed shrimp can be more 
susceptible to facultative pathogenic microorganisms that are part of their natural microbial flora and aquatic environment, ${ }^{65}$ which has been noticed in the control tanks of the present experiment. Crab et al. ${ }^{66}$ studied the role of biofloc to protect the brine shrimp (Artemia franciscana) from the pathogen Vibrio harveyi and concluded that biofloc technology constituted a possible alternative measure to fight pathogenic bacteria.

Our study showed that the survival rates in the control and biofloc tanks (with substrate) were higher than those without substrate. Schveitzer et al.$^{67}$ studied the effects of using artificial substrates in the culture of Litopenaeus vannamei (Biofloc system) at different stocking densities on the microbial activity, water quality and production rates. They concluded that the presence of substrates increased the surface area of the tanks and reduced the relative stocking densities; and consequently reduced the stress level of the shrimps, indicated by the higher survival rates. A positive impact of substrates on the production indices for the culture of post-larvae and juvenile shrimp has been reported by several authors..$^{26-28,61}$ Those authors concluded that the increase in the growth of the shrimp resulted in the reduction in the stocking density because of the presence of substrates. Nevertheless, the survival rates in the biofloc tanks (with substrate) were higher $(87.78 \%)$ than the control one $(76.67 \%)$ (Table 3). Numerous studies have reported enhanced survival, health, and growth rates of shrimp raised in ponds with high activity of algae, microbial floc, and other natural biota. ${ }^{20,23,24,39,40,42,68,69}$

\section{Nutritive quality of the shrimps' flesh}

Although the culture of shrimp in zero exchange systems is an increasing and extensive research that has been carried out in different areas of the world, the impact of biofloc on the proximate composition and flesh quality has not extensively been studied. In our study, shrimps in both treatments had suitable moisture contents (73.64-75.07\%). Moisture of fresh shrimp is generally reported as 75 to $80 \%{ }^{70}$ Protein was found as the major constituent indicating that shrimp flesh can be a good source of amino acids. ${ }^{71}$ Crude protein levels showed a tendency to increase in the shrimps raised in the biofloc treatments (Table 4). It has been reported that protein content of shrimp ranged between $17-21 \%$ depending on shrimp species. ${ }^{72}$ Only slight differences were found in the carbohydrate, fat and ash compositions among shrimps grown in the control and biofloc tanks, representing that the quality of flesh was not affected by any of the culture conditions used in this study. Proximate compositions in shrimps' flesh are affected by several factors such as species, growth stage, feed and season. ${ }^{73}$ It has been shown that organoleptic characteristics, quality of flesh, odor, texture and color of fish/shrimp depend on the conditions where they were captured or cultivated. ${ }^{74}$ In our study, the proximate compositions or nutritive quality parameters found for $P$. semisulcatus were within the range of other shrimp species. ${ }^{75-76}$

\section{Conclusion}

Our results corroborate with those of other studies that reported the positive impact of artificial substrates on the production indices of cultured shrimps; however, the substrates had no impact on the water quality parameters. Substrates served in increasing the surface area of the tank, thus reducing the relative stocking density, which accordingly lowered the stress levels on the shrimps indicated by the higher survival rate. In the biofloc system, carbon source addition in combination with the low protein diet (23\%) improved the sustainability of $P$. semisulcatus farming through increased growth rates, weight gain and reduced FCR. Consumption of microorganisms in BFT reduces FCR and consequently the costs of feed to nearly one-third. This work has demonstrated that the green tiger shrimp P. semisulcatus can be cultured in a biofloc system without losing its flesh quality.

\section{Acknowledgments}

None.

\section{Conflicts of interest}

None.

\section{References}

1. FAO. Cultured aquaculture species information programme Penaeus vannamei. Food and Agriculture Organization of the United Nations. 2008.

2. Kuhn DD, Boardman GD, Lawrence AL, et al. Microbial floc meal as a replacement ingredient for fish meal and soybean protein in shrimp feed. Aquac. 2009;296(1-2):51-57.

3. Ray WM, Chien YH. Effects of stocking density and aged sediment on tiger prawn, Penaeus monodon, nursery system. Aquac. 1992;104(34):231-248.

4. Hanson JE, Goodwin HL. Shrimp and prawn farming in the western hemisphere. Dowden, Hutchinson \& Ross, Stoudsburg, Pennsylvania. 1977;pp.439.

5. Allan GL, Maguire GB. Effects of PH and salinity on survival, growth and osmoregulation in Penaeus monodon Fabricius. Aquac. 1992;107(1):33- 47 .

6. Martin JL, Veran Y, Guelorget O, et al. Shrimp rearing: stocking density, growth, impact on sediment, waste output and their relationships studied through the nitrogen budget in rearing ponds. Aquac. 1998;164(14):135-149.

7. New MB. Feed and feeding of fish and shrimp. A manual of preparation and preservation of compound feeds for shrimp and fish in aquaculture. United Nations Development Program, Food and Agriculture Organization of the United Nations, Rome. 1987;pp.275.

8. Tacon AGJ. Standard methods for the nutrition and feeding of farmed fish and shrimp. Argent Laboratories Press, Washington DC, US. 1990;pp.454.

9. Suárez JA, Gaxiola G, Mendoza R, et al. Substitution of fish meal with plant protein sources and energy budget for white shrimp Litopenaeus vannamei (Boone, 1931). Aquac. 2009;289(1-2):118-123.

10. Tacon AGJ, Metian M. Global overview on the use of fish meal and fish oil in industrially compounded aquafeeds: trends and future prospects. Aquac. 2008;285(1-4):146-158.

11. Jonathan S, Andrew J, Jean FM. Fishmeal industry overview. International Fishmeal and Fish Oil Organization. 2007.

12. FAO. The State of World Fisheries and Aquaculture. Food and Agriculture Organization of the United Nations, Rome, Italy. 2008;pp.196.

13. Naylor RL, Hardy RW, Bureau DP, et al. Feeding aquaculture in an era of finite resources. Proc Natl Acad Sci. 2009;106(36):15103-15110.

14. FAO. The State of World Aquaculture. Food and Agriculture organization of the United Nations, FAO Fisheries Technical \& Fisheries Department, Rome, Italy. 2006;pp. 134.

15. Salze G, Mclean E, Battle PR, et al. Use of soy protein concentrate and novel ingredients in the total elimination of fish meal and fish oil in diets for juvenile cobia, Rachycentron canadum. Aquac. 2010;298(34):294-299.

16. Naylor RL, Goldburg RJ, Primavera JH, et al. Effect of aquaculture on world fish supplies. Nature. 2000;405(6790):1017-1024. 
17. Avnimelech Y, Ritvo G. Shrimp and fish pond soils: processes and management. Aquac. 2003;220(1-4):549-567.

18. Samocha TM, Lawrence AL, Collins CA, et al. Production of the Pacific white shrimp, Litopenaeus vannamei, in high-density greenhouseenclosed raceways using low salinity groundwater. J Appl Aquacult. 2004;15(3-4):1-19.

19. Horowitz A, Horowitz S. The New Wave-Proceedings of the Special Session on Sustainable Shrimp. In: Browdy CL \& Jory DE (Eds.), The World Aquaculture Society, Baton Rouge, Baton Rouge, Louisiana, US 2001;pp.199-218.

20. Avnimelech Y. Carbon/nitrogen ratio as a control element in aquaculture systems. Aquac. 1999;176(3-4):227-235.

21. Avnimelech Y. Biofilters: the need for a new comprehensive approach Agricult Eng. 2006;34(3):172-178.

22. Burford MA, Thompson PJ, McIntosh P, et al. Nutrient and microbial dynamics in high-intensity, zero-exchange shrimp ponds in Belize. Aquac. 2003;219(1-4):393-411.

23. Hari B, Kurup BM, Varghese JT, et al. The effect of carbohydrate addition on water quality and the nitrogen budget in extensive shrimp culture systems. Aquac. 2006;252(2-4):248-263.

24. Crab R, Chielens B, Wille M, et al. The effect of different carbon sources on the nutritional value of bioflocs, a feed for Macrobrachium rosenbergii post larvae. Aquacult Res. 2010a;41(4):559-567.

25. Megahed ME. The effect of microbial biofloc on water quality, survival and growth of the green tiger shrimp (Penaeus semisulcatus) fed with different crude protein levels, I: Sustainable solution to the dependency on fish oil, fishmeal and environmental problems. Journal of the Arabian Aquaculture Society. 2010;5(2):1-24.

26. Zhang B. Influence of the Artificial Substrates on the Attachment Behavior of Litopenaeus vannamei in the Intensive Culture Condition. Int J Anim Vet Adv. 2011;3(1):37-43.

27. Viau VE, Souza MD, Rodríguez EM, et al. Biofilm feeding by postlarvae of the pink shrimp Farfantepenaeus brasiliensis (Decapoda Penaidae). AquacultRes. 2012;44(5):783-794.

28. Arnold SJ, Sellars MJ, Crocos PJ, et al. Intensive production of juvenile tiger shrimp Penaeus monodon: an evaluation of stocking density and artificial substrates. Aquac. 2006;261(3):890-896.

29. Abdussamad EM, Thampy DM. Cannibalism in the tiger shrimp Penaeus monodon Fabricius in nursery rearing phase. J Aquacult. 1994; Trop 9(1):67-75

30. APHA. Standard Methods for the Examination of Water and Wastewater (19th edn), American Public Health Association, Washington, DC, USA. 1995.

31. Ricker WE. Computation and interpretation of biological statistics of fish population. B Fish Res Board Can. 1975;191:1-382.

32. Felix N, Sudharsan M. Effect of glycine betaine, a feed attractant affecting growth and feed conversion of juvenile fresh water prawn Macrobrachium rosenbergii. AquacultNutr. 2004;10(3):193-197.

33. Venkat HK, Narottam PS, Kamal KJ. Effect of feeding Lactobacillusbased probiotics on the gut microflora, growth and survival of postlarvae of Macrobrachium rosenbergii (de Man). Aquacult Res. 2004;35(5):501-507.

34. Lowry OH, Rosebrough NJ, Farr AL, et al. Protein measurement with the tolin phenol reagent. J Biol Chem. 1951;193(1):265-275.

35. Dubois M, Giles KA, Hamilton JK, et al. Calorimetric method for determination of sugar and related substances. Anal Chem. 1956;28(3):350-356.
36. Folch J, Lee M, Sloane-Stanley GH. A Simple method for the isolation and purification of total lipids from animal tissues. J Biol Chem. 1957;226(1):497-509.

37. AOAC. Official Methods of Analysis of AOAC International (18th edn), AOAC International, Gaithersburg, Maryland, USA. 2005.

38. Merrill AL, Watt BK. Energy Value of Foods: basis and derivation. United States Department of Agriculture (USDA), Handbook No. 74. 1973.

39. Wasielesky JW, Atwood H, Stokes A, et al. Effect of natural production in a zero exchange suspended microbial floc based super-intensive culture system for white shrimp Litopenaeus vannamei. Aquac. 2006;258(1-4):396-403.

40. Burford MA, Thompson PJ, McIntosh RP, et al. The contribution of flocculated material to shrimp (Litopenaeus vannamei) nutrition in a high intensity, zero-exchange system. Aquac. 2004;232(1-4):525-537.

41. Van Wyk P, Davis-Hodgkins M, Laramore CR, et al. Farming Marine Shrimp in Recirculating Freshwater Production Systems. Florida Department of Agriculture Consumer Services, Tallahassee, Florida, US. 1999.

42. Cuzon G, Lawrence A, Gaxiola G, et al. Nutrition of Litopenaeus vannamei reared in tanks or in ponds. Aquac. 2004;235(1-4):513-551.

43. Rosas CA, Sanchez E, Diaz-Iglesia E, et al. Critical dissolved oxygen level to Penaeus seterus and Penaeus schmitti post-larvae (PL10-18) exposed to salinity changes. Aquac. 1997;152(1-4):259-272.

44. Landman MJ, Van Den Heuvel MR, Ling N. Relative sensitivities of common freshwater fish and invertebrates to acute hypoxia. New Zeal J Mar Fresh. 2005;39(5):1061-1067.

45. Shih RK, Hsing JL, Kwang TS. Seasonal changes in abundance and composition of the fish assemblage in Chiku Lagoon, southwestern Taiwan. B Marine Science. 2001;68(1):85-99.

46. Olah J, Sinha RP, Ayyappan S, et al. Sediment consumption in tropical undrainable fish ponds. Int Revue ges Hydrobiol. 1987;72(3):297-305.

47. Ebeling JM, Timmons MB, Bisogni JJ. Engineering analysis of the stoichiometry of photoautotrophic, autotrophic, and heterotrophic removal of ammonia-nitrogen in aquaculture systems. Aquac. 2006;257(1-4):346-358

48. Ritvo G, Dixon JB, Lawrence AL, et al. Accumulation of chemical elements in Texas shrimp pond soils. $J$ World Aquac Soc. 1998;29(4):422430

49. Frias-Espericueta MG, Harfush-Melendez M, Osuna-Lopez JI, et al. Acute toxicity of ammonia to juvenile shrimp Penaeus vannamei Boone. Bull Environ Contam Toxicol. 1999;62(5):646-652.

50. Wickins JF. The tolerance of warm-water prawns to recirculated water. Aquac. 1976;9:19-37.

51. Allan GL, Maguire GB. Effects of stocking density on production of Penaeus monodon model farming ponds. Aquac. 1992;107(1):49-66.

52. Palomino G, Contreras F, Sanchez A, et al. Density and water exchangedependent growth and survival of Litopenaeus setiferus postlarvae. $J$ World Aquac Soc. 2002;32(2):167-176.

53. Tezuka Y. Bacterial regeneration of ammonium and phosphate as affected by the carbon: nitrogen: phosphorus ratio of organic substrates. Microb Ecol. 1990;19(3):227-238.

54. Hoch MP, Fogel ML, Kirchman DL. Isotope fractionation during ammonium uptake by marine microbial assemblages. Geomicrobiol. 1994;12(2):113-127.

55. Avnimelech Y, Diab S, Kochva M, et al. Control and utilization of inorganic nitrogen in intensive fish culture ponds. Aquacult Fish Manage. 1992;23(4):421-430. 
56. Avnimelech Y, Kochva M, Diab S. Development of controlled intensive aquaculture systems with a limited water exchange and adjusted carbon to nitrogen ratio. Isr J Aquacult Bamid. 1994;46:119-131.

57. Stuart JA, Frank EC, Chris JJ, et al. High-intensity, zero water-exchange production of juvenile tiger shrimp, Penaeus monodon: An evaluation of artificial substrates and stocking density. Aquac. 2009;293(1-2):42- 48.

58. Middelboe M, Borch NH, Kirchman DL. Bacterial utilization of dissolved free amino acids, dissolved combined amino acids and ammonium in the Delaware Bay estuary: effects of carbon and nitrogen limitation. Mar Ecol Prog Ser. 1995;128:109-120.

59. Wyban JA, Lee CS, Sato VT, et al. Effect of stocking density on shrimp growth rates in manure-fertilized ponds. Aquac. 1987;61(1):23-32.

60. Otoshi CA, Naguwa SS, Falesch FC, et al. Shrimp behavior may affect culture performance at super-intensive stocking densities. Glob Aquacult Advo. 2007;2:67-69.

61. Otoshi CA, Montgomery AD, Matsuda EM, et al. Effects of Artificial Substrate and Water Source on Growth of Juvenile Pacific White Shrimp, Litopenaeus vannamei. J World Aquac Soc. 2006;37(2):210213.

62. Hari B, Kurup BM, Varghese JT, et al. Effects of carbohydrate addition on production in extensive shrimp culture systems. Aquac. 2004;241(14):179-194.

63. Suresh AV, Lin CK. Effect of stocking density on water quality and production of red tilapia in a recirculated water system. Aquacult Eng. 1992;11(1):1-22.

64. Araneda M, Pérez EP, Gasca-Leyva E. White shrimp Penaeus vannamei culture in freshwater at three densities: Condition state based on length and weight. Aquac. 2008;283(1-4):13-18.

65. Lightner DV. Biosecurity in Shrimp Farming: Pathogen Exclusion through Use of SPF Stock and Routine Surveillance. J World Aquac Soc. 2005;36(3):229-248.

66. Crab R, Lambert A, Defoirdt T, et al. Bioflocs protect gnotobiotic brine shrimp (Artemia franciscana) from pathogenic Vibrio harveyi. J Appl Microbiol. 2010;109(5):1643-1649.

67. Schveitzer R, Arantes R, Baloi MF, et al. Use of artificial substrates in the culture of Litopenaeus vannamei (Biofloc System) at different stocking densities: effects on microbial activity, water quality and production rates. Aquacult Eng. 2013;54:93-103.
68. Loureiro CK, Wasielesky Jr W, Abreu PC. The use of protozoan, rotifers and nematodes as live food for shrimp raised in BFT system. Atlantica, Rio Grande. 2012;34(1):5-12.

69. Baloi M, Arantes R, Schveitzer R, et al. Performance of Pacific white shrimp Litopenaeus vannamei raised in biofloc systems with varying levels of light exposure. Aquacult Eng. 2013;52:39- 44.

70. Yanar Y, Celik M. Seasonal amino acid profiles and mineral content of green tiger shrimp (Penaus semisulcatus, De Haan, 1844) and speckled shrimp (Metapenaus monoceros, Fabricus 1789) from the Eastern Mediterranean. Food Chem. 2006;94(1):33-36.

71. Puga-lópez D, Ponce-palafox JT, Barba-quintero G, et al Physicochemical, proximate composition, microbiological and sensory analysis of farmed and wild harvested white shrimp Litopenaeus vannamei (Boone, 1931) tissues. Curr Res J Biol Sci. 2013;5(3):130 135 .

72. Sriket P, Benjakul S, Visessanguan W, et al. Comparative studies on chemical composition and thermal properties of black tiger shrimp (Penaeus monodon) and white shrimp (Penaeus vannamei) meats. Food Chem. 2007;103(4):1199-1207.

73. Karakoltsidis PA, Zotos A, Constantinides SM. Composition of the commercially important Mediterranean finfish: Crustaceans and molluscs. J Food Comp Anal. 1995;8(3):258-273.

74. Grigorakis K. Compositional and organoleptic quality of farmed and wild gilthead sea bream (Sparus aurata) and sea bass (Dicentrarchus labrax) and factors affecting it: A review. Aquac. 2007;272(1-4):55-75.

75. Oksuz a, Ozyilmaz a, Aktas M, et al. A comparative study on proximate, mineral and fatty acid compositions of deep seawater rose shrimp (Parapenaeus longirostris, Lucas 1846) and red shrimp (Plesionikamartia, A. Milne-Edwards, 1883). J Anim Vet Adv. 2009;8(1):183-189.

76. Turan H, Kaya Y, Erdem ME. Proximate composition, cholesterol and fatty acid content of brown shrimp (Crangon crangon L. 1758) from sinop region, black sea. J Aquat Food Prod T. 2011;20(1):100-107. 